\title{
KESALAHAN GRAMATIKAL KARENA PENGARUH BAHASA IBU DALAM TULISAN MAHASISWA PROGRAM STUDI SASTRA INGGRIS FAKULTAS ILMU BUDAYA UNIVERSITAS UDAYANA
}

\author{
Yana Qomariana, Ida Ayu Made Puspani, dan Ni Ketut Sri Rahayuni \\ Universitas Udayana \\ yqomariana@gmail.com; dayupuspani@gmail.com; \& ketutsrirahayuni@gmail.com
}

\begin{abstract}
Abstrak
Dalam pembelajaran bahasa asing atau bahasa kedua seringkali dijumpai kesulitan yang dilakukan oleh pembelajar. Kesulitan tersebut antara lain disebabkan oleh adanya perbedaan antara bahasa asing yang dipelajari (L2) dengan bahasa ibu pembelajar (L1). Terdapat kesalahan pembelajar yang dipengaruhi oleh L1. Kesalahan-kesalahan tersebut bisa terjadi pada bidang fonologi, kosa kata, dan tata bahasa (Breadsmore, 1982). Perbedaan ini menyebabkan kesalahan-kesalahan dalam penggunaan L2 oleh pembelajar. Hal ini menunjukkan pengaruh dari L1 terhadap pemerolehan L2 (Ellis in Bhela, 1999).

Penelitian ini bertujuan menganalisa pengaruh bahasa ibu terhadap bahasa Inggris mahasiswa program studi Sastra Inggris, Fakultas Ilmu Budaya, Universitas Udayana, bahasa Bali dianggap sebagai bahasa Ibu mahasiswa. Kedua bahasa akan dibandingkan untuk menganalisa perbedaan dan persamaan diantara keduanya. Responden dalam penelitian adalah mahasiswa semester dua Program Studi Sastra Inggris yang akan dianalisa kemampuan menulisnya dalam Bahasa Inggris. Tulisan mahasiswa kemudian akan dianalisa berdasarkan kesalahan yang ditemukan, khususnya dalam hal morfologi dan sintaksis. Selanjutnya, kesalahan-kesalahan tersebut dianalisa berdasarkan perbedaan antara L1 dan L2 yang menyebabkan terjadinya kesalahan.
\end{abstract}

Kata-kata kunci: bahasa ibu, error analysis, kesalahan gramatikal

\section{Pendahuluan}

Bahasa Inggris telah mendapatkan pengakuan sebagai bahasa internasional yang berperan sangat penting dalam lalu lintas pengetahuan pada saat ini. Sehingga sangat penting untuk mempunyai kemampuan berbahasa Inggris, baik kemampuan receptive, yaitu mendengar (listening) dan membaca (reading), maupun kemampuan productive, yaitu berbicara (speaking) dan menulis (writing). Kemampuan berbahasa Inggris menjadi kunci sukses dalam berbagai akifitas, karena kemampuan ini memungkinkan lancarnya komunikasi dan transfer informasi terbaru.

Pembelajaran bahasa Inggris dipengaruhi oleh beberapa faktor, antara lain kemampuan menerima ilmu bahasa Inggris, motivasi belajar, umur, tujuan berkarir, waktu penggunaan bahasa Inggris, dan bahasa Inggris untuk kesenangan (Latu, 1994). Faktor penerimaan bahasa Inggris dipengaruhi oleh dasar kemampuan berbahasa termasuk bahasa ibu. Bahasa ibu dengan tata bahasa yang berbeda menyebabkan kesulitan tertentu dalam pembelajaran bahasa Inggris. Banyak ditemukan kesalahan-kesalahan pada pembelajar bahasa Inggris yang bahasa ibunya mempunyai tata bahasa yang jauh berbeda dengan tata bahasa Inggris. Kesalahan-kesalahan tersebut bisa dilacak sampai pada faktor tata bahasa dalam bahasa ibu yang menyebabkan kesalahan tersebut. Breadsmore (1982) menyampaikan bahwa pengaruh bahasa ibu bisa muncul pada bidang fonologi, kosa kata, dan tata bahasa. Pengaruh bahasa ibu bisa diamati melalui produksi pembelajar dalam berbahasa Inggris, yaitu keahlian berbicara (speaking) dan menulis (writing).

Tulisan ini menganalisa pengaruh bahasa ibu terhadap tulisan mahasiswa. Kesalahan-kesalahan gramatikal yang dijumpai dalam karangan berbahasa Inggris yang ditulis oleh mahasiswa menunjukkan pengaruh bahasa ibu. Bahasa Bali dianggap sebagai Bahasa Ibu karena bahasa Bali dipelajari sejak dari kecil. Kesalahan yang dijumpai, misalnya kesalahan dalam bidang kata kerja, karena bahasa Bali tidak merefleksikan jumlah dan kala seperti Bahasa Inggris. Waktu kejadian ditunjukkan oleh kata keterangan, misalnya jani 'sekarang' atau mani 'besok'. Kata ganti orang juga tidak berpengaruh terhadap kata kerja. Bentuk kata ganti orang dan kata benda juga 
tidak dipengaruhi oleh jumlah, apakah tunggal atau jamak. Masalah lain yang sering dijumpai oleh pembelajar Bahasa Inggris adalah artikel $a$ dan the yang tidak digunakan dalam bahasa ibu.

\section{Tinjauan Pustaka}

Diskusi mengenai pembelajaran bahasa ke dua (L2) tidak bisa lepas dari peran bahasa pertama (L1). Bahasa pertama mengacu kepada bahasa yang dipelajari sebelum umur tiga tahun (Sinha dan Shastri dalam Derakhsan, 2005). Bahasa pertama juga seringkali disebut sebagai bahasa ibu 'mother tongue' atau bahasa asli 'native language'. Bahasa ibu sendiri diidentifikasi sebagai bahasa pertama yang dipelajari pada masa anak-anak (Manrique, 2012). Sedangkan bahasa ke dua mengacu kepada bahasa lain yang dipelajari setelah bahasa pertama, misalnya Bahasa Inggris yang menurut kurikulum nasional mulai diajarkan pada tingkat sekolah dasar.

Pengaruh bahasa Ibu (L1) terhadap bahasa lain yang dipelajari (L2) telah banyak didiskusikan. Istilah pengaruh juga disebutkan sebagai interferensi. Menurut Dulay et. all (in Bhela, 1999) pengaruh bahasa Ibu merupakan perpindahan surface structure L1 kepada surface structure L2 yang terjadi dalam penggunaan L2. Sedangkan Ellis (dalam Bhela, 1999) menyatakan bahwa pada pembelajaran bahasa kedua terdapat pengaruh dari L1 yang terbawa pada proses pemerolehan L2.

Menurut Noor (dalam Manrique, 2012) bahasa ibu bisa berpengaruh secara positif maupun negatif. Jika terdapat persamaan antara bahasa ibu dan bahasa kedua, bahasa ibu akan memberikan pengaruh positif, sedangkan jika terdapat perbedaan maka bahasa ibu akan berpengaruh secara negatif.

Tujuan dari pembelajaran bahasa adalah penguasaan terhadap bahasa tersebut setelah melalui proses pembelajaran. Pada pembelajaran bahasa Inggris, pembelajar diharapkan dapat memproduksi bahasa Inggris sesuai dengan tata bahasanya. Tetapi banyak pembelajar yang menunjukkan kesalahan dalam berbahasa Inggris setelah suatu periode belajar. Ini adalah hal yang umum dijumpai dalam pembelajaran bahasa Inggris. Seperti yang disampaikan oleh Breadsmore (1982). Kesalahan-kesalahan yang terjadi disebabkan oleh kebiasaan penggunaan tata bahasa ibu ketika pembelajar menggunakan bahasa Inggris. Hal ini menunjukkan adanya pengaruh bahasa Ibu terhadap penggunaan bahasa Inggris.
Lebih lanjut, dijelaskan oleh Dechert (1983) bahwa kesalahan-kesalahan yang ditemukan dalam produksi L2 oleh pembelajar bisa dilacak sampai pada L1 yang menunjukkan adanya pengaruh L1 terhadap pemerolehan L2.

Banyak penelitian sudah dilakukan mengenai pengaruh bahasa Ibu terhadap pembelajaran bahasa ke dua. Salah satunya adalah penelitian yang di lakukan oleh Manrique (2012) di satu universitas negeri di Colombia. Penelitian in dilakukan oleh untuk melihat pengaruh bahasa ibu pada penggunaan bahasa Inggris. Sumber data penelitian ini adalah mahasiswa yang baru mulai belajar di universitas tersebut. Hasil penelitian ini menunjukkan adanya pengaruh negatif dari bahasa Spanyol sebagai bahasa Ibu pada bahasa Inggris yang diproduksi oleh informan. Kesalahan yang paling banyak ditemukan pada level fonologi dan tata bahasa. In the fonologi level terdapat satu bunyi yang sering ditemukan hilang dalam pengucapan bahasa Inggris, yang dipengaruhi dari kebiasaan ketika menggunakan bahasa Ibunya. Pada tata bahasa pengaruh bahasa Spanyol ditunjukkan dengan penghilangan subyek kalimat yang dalam bahasa Spanyol tidak mempengaruhi arti kalimat, sedangkan dalam bahasa Inggris hal ini adalah satu kesalahan.

Pengaruh bahasa ibu pada level frase didiskusikan dalam artikel yang ditulis oleh Thyab (2016). Tulisan ini menganalisa kesalahan pemakaian article pada penulisan bahasa Inggris oleh pembelajar yang mempunyai bahasa Arab sebaga bahasa ibu. Kesalahan ini disebabkan adanya perbedaan sistem artikel pada kedua bahasa, terutama pada sistem definite dan indefiniteness artikel dalam bahasa Inggris yang tidak dijumpai dalam bahasa Arab. Dalam bahasa Arab artikel digolongkan berdasarkan jenis dan jumlah suatu barang.

Masalah fonologi juga ditemui pada pembelajar bahasa Inggris di Cina seperti ditulis oleh Luo (2014). Bunyi yang menjadi masalah utama yang dialami pembelajar si Cina adalah [1], $[\mathrm{n}],[\mathrm{f}]$ and $[\mathrm{h}]$. Pengaruh bahasa Ibu sangat jelas terlihat pada kesalahan pengucapan anatara kata [knife] dan [life]. Jika dilihat berdasarkan pebedaan bunyi antara dua bahasa tersebut, terdapat perbedaan besar yaitu dua puluh vowels (huruf hidup) dan dua puluh empat consonants (huruf mati); sedangkan dalam bahasa Cina terdapat enam vowels (huruf hidup), dua puluh lima consonants (huruf mati) dan 4 tone. Dalam beberapa dialek bahasa Cina, bunyi [ 1] dan [ $\mathrm{n}$ ] 
adalah kelompok suara yang mewakili phoneme yang sama.

Sebuah penelitian mengenai pengaruh bahasa ibu di daerah pedesaan di Sarawak, Malaysia. Tulisan Suliman (2014) menunjukkan pengaruh negatif bahasa ibu terhadap pembelajaran bahasa Inggris. Kemampuan berbahasa Inggris adalah hal yang penting di Malaysia karena dengan banyaknya etnis yang bertempat tinggal di Malaysia, bahasa Inggris menjadi alat komunikasi di dunia bisnis, interaksi sosial dan satu bahasa internasional yang dipakai di Malaysia. Penelitian dilakukan pada pelajar di dua sekolah di Sarawak. Para pelajar sebagai responden diteliti kemampuan berbicaranya dalam bahasa Inggris. Hasil penelitian menunjukkan adanya kesalahan di bidang morfologi dan syntax. Pengaruh negatif bahasa ibu bisa diamati dengan jelas karena dalam berbicara, responden menerjemahkan bahasa ibunya ke dalam bahasa Inggris.

Istilah kesalahan dalam bahasa Inggris bisa disebut sebagai mistakes atau errors. Dua istilah tersebut mengacu kepada dua hal yang berbeda. Mistake mengacu kepada kesalahan yang dibuat oleh pembicara karena pembicara tidak memahami aturan mengenai kesalhan tersebut. Errors adalah kesalahan yang terjadi karena kecerobohan pembicara; pembicara paham mengenai aturan dalam suatu bahasa yang digunakan tetapi melakukan kesalahan yang menentang aturan tersebut (Ellis dalam Bhela, 1999).

Error Analysis (EA) diperkenalkan oleh Richard (1974) yang digunakan untuk mengidentifikasi kesalahan. EA adalah bagian dari ilmu linguistic terapan yang digunakan untuk mengidentifikasi, mendeskripsikan dan menjelaskan kesalahan pengguna bahasa dalam ucapan atau tulisan (Ellis dan Barkhizen dalam Amiri dan Puteh, 2017). James (dalam Sermsook et al., 2017 membagi errors atau kesalahan dalam lima jenis, yaitu: (1) kesalahan gramatikal yang meliputi: (1) kesalahan gramatikal yang mencakup: kesalahan penggunaan kata sifat, kata keterangan (adverbs), artikel, kata benda, kepemilikan, kata ganti orang, preposisi, dan kata kerja; (2) substance errors: penggunaan huruf capital, tanda baca dan ejaan; (3) kesalahan leksikal: bentuk dan pilihan kata; (4) kesalahan sintaksis: koordinasi/subordinasi, struktur dan susunan kalimat; (5) kesalahan semantic yang mengacu kepada komunikasi yang bermakna ganda dan kesalahan komunikasi. Kesalahan dalam bidang syntax adalah salah satu kesalahan yang paling sering ditemukan dalam proses pembelajaran bahasa Inggris.

\section{Metodologi}

Metode penelitian berisikan tahapan-tahapan untuk melakukan penelitian. Tahapan-tahapan ini adalah bagian penting dalam penelitian karena fungsinya untuk memastikan penelitian bersifat ilmiah dan mempunyai hasil yang valid. Penelitian ini menerapkan pendekatan deskriptif kualitatif, di mana data dideskripsikan berdasarkan teori yang digunakan.

Metode penelitian ini terdiri dari tiga bagian yaitu, sumber data, metode pengumpulan data, dan metode analisa data. Masing-masing bagian penelitian tersebut dijelaskan dalam bagian tersendiri di bawah ini. Selain itu bagian Metode Penelitian ini juga dilengkapi dengan Bagan Alir yang memuat langkah-langkah penelitian secara ringkas.

Sumber data dalam penelitian ini adalah 40 karangan naratif berbahasa Inggris mahasiswa semester dua Program Studi Sastra Inggris, Fakultas Ilmu Budaya Universitas Udayana. Mahasiswa semester dua dipilih sebagai responden karena diasumsikan masih bisa menunjukkan kemampuan awal bahas Inggris mereka. Tugas menulis karangan diberikan dengan topik tertentu yang panjangnya 230 kata dalam waktu 60 menit.

Karangan mahasiswa dianalisa untuk mencatat kesalahan-kesalahan pada tulisan mahasiswa. Kesalahan-kesalahan ini dianalisa menurut metode error analysis yang merupakan cara untuk mengidentifikasi area kesulitan pembelajar bahasa dengan sistem penerapan perbedaaan formal antara bahasa pertama pembelajar (L1) dengan bahasa kedua (L2) (Corder and Dulay in Usha dan Kader, 2016). Kesalahan kemudian diklasifikasikan berdasarkan tipe-tipe kesalahan berdasarkan grammar Bahasa Inggris. Selanjutnya, tipe-tipe kesalahan tersebut dibandingkan dengan tata bahasa dalam bahasa Ibu untuk mengetahui pengaruh L1 terhadap L2.

\section{Hasil dan Pembahasan}

Data penelitian menunjukkan kesalahankesalahan dalam tulisan mahasiswa. Kesalahankesalahan tersebut dikategorikan dalam tujuh tipe kesalahan, yaitu: (1) kala; (2) kesesuaian subyek dan kata kerja; (3) susunan kata; (4) kata ganti orang, (5) benda tunggal/jamak; (6) konstruksi pasif/aktif, dan (7) artikel. Kesalahan-kesalahan 
tersebut menunjukkan pengaruh L1 atau bahasa Ibu terhadap L2.

Tabel 1 di bawah ini menunjukkan ringkasan kesalahan-kesalahan yang ditemukan sebagai interferensi bahasa ibu dalam karangan mahasiswa.

Tabel 1 Interferensi Bahasa Ibu dalam Karangan Mahasiswa

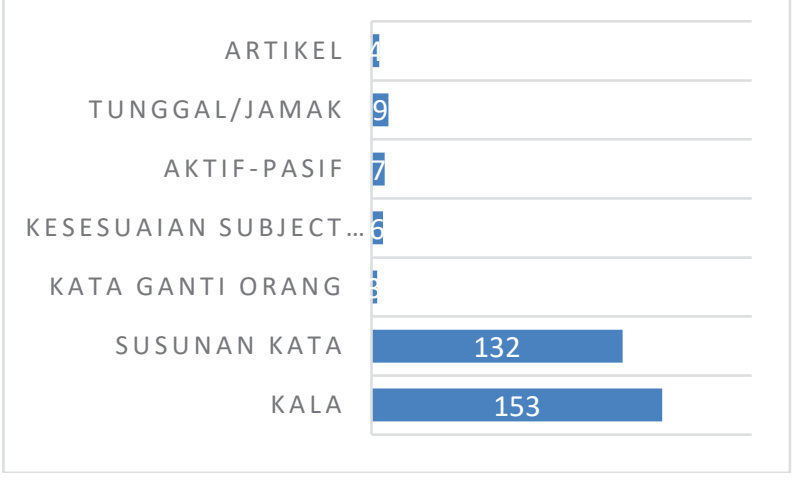

Tabel di atas menunjukkan interferensi yang paling besar ditunjukkan oleh kesalahan dalam bidang kala. Berikut adalah data kesalahan-kesalahan dalam bidang kala.

(1) When I stayed in Perth, there is a 0105 family as my host.

(2) In my holiday, we leave from Bali to 0105 Jakarta by plane

(3) I enjoy the travelling by watching 0106 movies.

(4) I choose my best friend to be my 0109 roommate.

(5) My best experience happen in about 0109 five years ago.

Susunan kata atau word order adalah kesalahan terbanyak kedua dalam karangan mahasiswa. Total terdapat 132 kesalahan di bidang susuanan kata. Yang termasuk dalam kesalahan ini adalah kesalahan yang melanggar aturan urutan kata dalam kalimat Bahasa Inggris. Dalam kalimat no (6), to seharusnya diikuti oleh V1 bukan understod. Hal yang sama juga bisa dilihat dalam kalimat (7). Pada kalimat (9) kata kerja yang digunakan setelah modal seharusnya berbentuk kata kerja bentuk pertama. Sedangkan kesalahan pada kalimat (9) dan (10) adalah hilangnya to be was.
(6) I thought, it would be so hard to 0106 understood a new culture.

(7) I just talked if I had to talked. 0111

(8) I could faced everything when I was 0112 there

(9) I _ able to enter the most favourite 0238 senior high school there.

(10) When I__ back home. 0232

Konstruksi pasif juga menjadi kesulitan bagi mahasiswa. Dalam kalimat no (11) terdapat kesalahan konstruksi pasif Bahasa Inggris. Kata kerja pada kalimat no (11) adalah terjemahan langsung dari kata kerja 'terlihat', yang disampaikan dalam bentuk pasif; sedangkan dalam bahasa Inggris kata kerja ini seharusnya disampaikan dalam bentuk kata kerja aktif, "She looked more happer than me". Walaupun berbentuk aktif, kalimat ini mempunyai arti pasif terlihat.

(11) She was look more happier than me. 0234

Tipe kesalahan yang lain adalah kesesuaian antara Subyek dan kata kerja atau Subject-Verb agreement. Dalam data karangan mahasiswa, ditemukan 6 kesalahan tipe ini. Kesalahan tipe ini banyak ditunjukkan oleh tidak digunakan akhiran $s$ atau -es dalam kata kerja dalam kalimat dengan subyek orang ketiga tunggal. Perbandingan sistem ini dengan sistem dalam bahasa ibu mahasiswa menunjukkan perbedaan bahwa dalam bahasa ibu kata kerja tidak terefleksi dengan subyek dan kala (tense).

(12) Trans Jogja is so good because it is 0110 clean, comfy and also reach most Jogja's famous destination.

(13) In the second session, presidium 0115 give two motions.

Akhiran $-s$ dan - es juga muncul dalam penggunaan kata benda terhitung jamak. Sistem ini juga tidak terdapat dalam bahasa ibu, sehingga pada kalimat di bawah ini, terdapat penggunaan akhiran $-s$ pada kata benda yang seharusnya tunggal. Hal ini melanggar aturan dalam grammar Bahasa Inggris. Sedangkan kalimat (15) menunjukkan hal yang sebaliknya, akhiran $-s$ seharusnya digunakan pada kata benda jamak destinations. 
(14) It is such a big things for people to 0120 travel abroad.

(15) Nami island is one of my favourite 0213 destination in South Korea.

Artikel $a$ dan the juga tidak terdapat dalam tata bahasa ibu mahasiswa. Hal in menimbulkan kesulitan yang ditunjukkan oleh kesalahan pengunaan artikel tersebut dalam karangan mahasiswa yang terdapat dalam kalimat (19).

The second session. presidium 0238 give two motions.

Kesalahan lain yang disebabkan oleh interferensi bahasa ibu adalah bentuk kata ganti orang. Kata ganti orang dalam bahasa Inggris dibagi berdasarkan orang ke berapa, jumlah orang tunggal atau jamak, dan posisinya dalam kalimat (kata ganti orang subyek, obyek atau kepemilikan possessive pronoun). Sistem yang komplek ini berbeda dengan kata ganti orang dalam bahasa Indonesia dan bahasa Bali yang hanya dibagi berdasarkan orang ke berapa saja. Hal ini menjadi masalah yang tercermin dari kesalahan penggunaan kata ganti orang dalam karangan mahasiswa.

(20 We sat in the destination and ate we 080 food together.

Pada kalimat (20), penggunaan kata ganti orang we adalah salah, karena kata ganti orang ini berfungsi sebagai kata ganti orang kepemilikan our.

\section{Kesimpulan dan Saran}

Hasil penelitian menunjukkan adanya tujuh tipe kesalahan gramatikal dalam karangan mahasiswa. Kesalahan gramatikal tersebut juga menunjukkan interferensi bahasa ibu. Perbedaan sata bahasa tersebut termasuk penggunaan kata kerja dan modal kata kerja, tidak adanya penanda pada kata kerja yang mewakili kala dan jumlah, tidka adanya penanda jamak pada kata benda jamak, penggunaan artikel an dan the, dan penggunaan bentuk- bentuk kata ganti orang.

Penelitian ini memberikan hasil yang lebih baik jika menggunakan data yang lebih besar dan juga bisa dibandingkan dengan karangan serupa yang ditulis dalam bahasa Indonesia, sehingga kesalahan gramatikal yang ditemukan dalam karangan berbahasa Inggris bisa dibandingkan dengan karangan yang berbahasa Indonesia dan selanjutnya bisa dianalisa sebagai intereferensi bahasa ibu dengan lebih tepat.

\section{Daftar Pustaka}

Bhela, Baljit. 1999. Native Language Interference in Learning Second Language: Exploratory Case Studies of Native Language Interference with Target Language Usage in International Education Journal Vo 1, no 1, 1999. Retrieved from https:/ehlt.flinders.edu.au/education/iej/artic $\underline{\text { les/v1n1/bhela/bhela.pdf }}$

Breadsmore, H.B. 1982. Bilingualism: Basic Principles. Tieto, Avon

Derakhsan, Ali. 2015. The Interference of First Language and Second Language Acquisition in Theory and Practce in Language Studies. Vol 5, o 10, pp. 2112-2117, October 2015

Dulay, Heidi, Burt, Marina, Krashen, Stephen. 1982. Language Two. Oxford: OUP

Jack. C. Richards. 1974. Error Analysis: Perspective on Second Language Acquition. Longman

Latu, M. F. 1994. Factors Affecting The Learning of English as A Second Language Macroskills Among Tongan Secondary Students. Retrieved from http://ro.ecu.edu.au/theses/1110 on 02/10/2019;21:18

Manrique, Claudia Marcela Rubio.1999. Mother Yongue Interference with Foreign Language: A Case Study About A2 Oral Production in Colombian Public University. In Opening Writing Doors Journals Vol 9, No 1. Retrieved from http://revistas.unipamplona.edu.co/ojs vicei nves/index.php/OWD/article/view/266 on $\underline{02 / 10 / 2019} ; 21: 29$

Richards, J.C. 1974. Error Analysis: Perspectives on second language acquisition. London: Longman.

Sermsook, Kanyakorn, Liamnimitr, Jiraporn, and Pochakorn, Rattanakorn. 2017. An Analysis of Errors in Written English Sentences: A Case Study of Thai EFL Students in English Language Teaching; Vol. 10, No. 3 pg. 101 110 
Suliman, Ashairi. 2014. The Interference of Mother Tongue/Native Language in One's English Language Speech Production in International Journal of English and Education Vol 3, Issue 3, July 2014. Retrieved from http://ijee.org/yahoo_site admin/assets/docs/ 33.184152120.pdf on 02/10/2019; 20:14

Thyab, Rana Abid. 2016. Mother Tongue Interference in The Acquisition of English Articles by L1 Arab Students in Journal Education and Practice Vol 7, No 3, 2016. Retrieved from

_on $02 / 10 / 2019 ; 21: 40$
https://eric.ed.gov/?id=EJ1089791 on 02/10/2019 20:15

Usha, P and Kader, Noora Abdul. 2016. Syntactic and Morphological Error Analysis in English Language among Secondary Students of Kerala in IOSR Journal of Humanities and Social Sciences Volume 21, Issue 2, Ver. 1 (Feb 2016) pp 99-103.

Retrieved from http://www.iosrjournals.org/iosr-

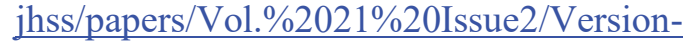
1/N0212199103.pdf 